Article

\title{
Racialized Affectivities of (Un)Belonging: Mixed (Race) Couples in the Shadow of Brexit
}

\author{
Elena Zambelli
}

Amsterdam Centre for Migration and Refugee Law, Faculty of Law, Vrije Universiteit Amsterdam, 1081 HV Amsterdam, The Netherlands; e.zambelli@vu.nl

Received: 11 June 2020; Accepted: 11 July 2020; Published: 1 August 2020

\begin{abstract}
This paper explores the affective economy of (un)belonging, revealed by the UK decision to withdraw from the European Union (EU). Emerging social science research on so-called 'Brexit' focuses on the anticipated effects of a stricter UK immigration regime on the lives of EU citizens and families. Against the background of the country's postcolonial melancholia, and drawing from my ethnographic fieldwork in England (2018-2019), this paper discusses how British and mixed-migration status, mixed (race) couples narrate the impact of the poll's outcome on their affective orientations towards the UK and the EU. It shows how race inflects partners' different perception of Brexit as a historical rupture or as an event in a continuum; as a loss of entitlement to mobility in space, or of the legitimacy of permanence in place; as a lingering danger, or a magnifier of existing patterns of violence. By putting Black and mixed-race partners' narratives center stage, this paper traces three scenes of expression of their perceived contested and precarious belonging: the ordinariness of racism in the UK, the mistrust in the durability of the boundaries of inclusion drawn by the British state, and a heightened alertness for fear of escalating racist and homophobic violence.
\end{abstract}

Keywords: Brexit; racism; Windrush; white habitus; affective economy; intersectionality; interracial couples; mixed-race couples; mixed-migration status couples

\section{Introduction}

This paper explores the racialized 'affective economy' (Ahmed 2004) ${ }^{1}$ of (un)belonging revealed by the UK decision to withdraw from the European Union (EU). Notwithstanding analytical differences in the relative weight of race and class in enabling the victory of the Leave position at the 23 June 2016 EU membership referendum (hereinafter 'the referendum'), scholars widely agree that it leveraged on the trope of 'excessive immigration' (Dennison and Geddes 2018; Rzepnikowska 2019; Valluvan and Kalra 2019). The result, therefore, foreshadowed a new, stricter UK immigration system to replace the EU freedom of movement regime, which represented at one and the same time the flagship property of EU citizenship ${ }^{2}$ and the culprit behind Britain's immigrant 'invasion'. ${ }^{3}$ Since then, the nature and

1 Drawing from Marxian and psychoanalytic approaches, Sarah Ahmed describes affect as a 'form of capital' emerging from the circulation, distribution and unequal accumulation of emotions 'across a social as well as psychic field.' (Ahmed 2004, p. 120), The resulting 'affective economy' produces and surfaces 'bodies and worlds' (ibid., p. 117) which are discursively organized through alignment and disavowal. She develops this concept by focusing on the circulation of hate and fear in white supremacist and xenophobic discourses, as the binding together of white bodies and the nation contextually produces the alignment and disavowal of bodies racialized as not-white.

2 'Freedom of movement and residence for persons in the EU is the cornerstone of Union citizenship, established by the Treaty of Maastricht [Treaty on the Functioning of the European Union] in 1992.' (Marzocchi 2020).

3 'By 2014, movement to the UK by EU citizens had overtaken annual non-EU net migration and by 2015 it had reached nearly 350,000 per annum.' (Dennison and Geddes 2018, p. 1145). Moreover, ' $69 \%$ of EU citizens residing in the UK arrived in the past five years.' (Grütters et al. 2018, p. 24). 
shape of the UK's post-Brexit relationship with the EU has kept on waxing and waning amidst heated political rivalries and quandaries. In the meantime, migration scholars have been investigating the potential impact of changing terms of acquisition, and loss of citizenship, residency and cognate rights, on the lives of EU-27 citizens and families residing in the UK (see for example Lessard-Phillips and Lessard-Phillips and Sigona 2018; Moreh et al. 2020; Yeo 2018a), and British citizens in the EU-27 (Benson 2019; Benson and Lewis 2019). ${ }^{4}$

Here, I depart from a similar future-oriented socio-legal analysis to take Brexit as a lens through which to analyze the relationship between race, the body and the place which is, or becomes, 'home'. 'Belonging' is, in Lauren Berlant's words, 'a specific genre of affect, history, and political mediation that cannot be presumed and is, indeed, a relation whose evidence and terms are always being contested.' (Berlant 2016, p. 395). In this article, I explore this contested, shifting and contingent nature of belonging by looking at the affective economy it reflects, engenders, and reproduces in the relationship between the (British) state and its subjects. This, I contend, requires an exploration into how its uneven circulation, distribution, and accumulation surfaces in subjects' different perceptions of entitlement and precariousness; confidence and mistrust; safety and fear. I do so by discussing how British and mixed-migration status, 'mixed (race) couples' narrate the impact of Brexit on their orientations towards the UK and the EU. First, I show how race inflects partners' different perception of Brexit as a historical rupture or as a continuum; as a loss of entitlement to mobility in space, or of the legitimacy of permanence in place; as a lingering danger, or a magnifier of existing patterns of violence. Second, by putting Black and mixed-race partners' narratives center stage, I foreground three scenes of expression of their perceived contested and precarious belonging: the ordinariness of racism in the UK, the mistrust in the durability of the boundaries of inclusion drawn by the state, and a heightened alertness for fear of escalating racist and homophobic violence.

Empirically, this paper contributes to existing scholarship on Brexit by bringing together the narratives of couples whose interraciality ${ }^{5}$ intersects with different moments in the history of the UK's post-WWII regulation of immigration, thereby enabling an interrogation of patterns of continuity and change over time. Moreover, the inclusion of both heterosexual and same-sex couples redresses the implicit heteronormative framework, underlying much research on interracial couples (but see Onwuachi-Willig 2013; Steinbugler 2012). ${ }^{6}$ Theoretically, this paper brings critical race theory, migration studies and legal anthropology into conversation with each other. In particular, it contends that the perceptions of mistrust and heightened alertness emerging from the narratives of subjects (i.e., partners) who were, until recently, lawfully discriminated on the basis of race and/or sexuality convey their awareness of the fickle nature of the boundaries of belonging, which the state draws, redraws, and withdraws.

This paper is structured as follows. First, I describe the research methodology and outline the profile of the research participants. Next, I contextualize my research, blending a review of relevant scholarship with my fieldwork observations. In the subsequent three sections, I discuss the racialized affectivities of (un)belonging emerging from the narratives of British and mixed-migration status, mixed (race) couples. In the conclusions, I synthesize my arguments.

4 Without the UK, the EU consists of twenty-seven Member States (MS)—hence the term 'EU-27'.

5 Jin Haritaworn speaks of 'interracialized' (Haritaworn 2012) intimacies, thereby stressing the processual (versus ontological) character of this category as well as of the 'races' object of the purported 'mix'. Although I acknowledge and share their critique, in this paper I maintain the terms 'interraciality' and 'interracial' for their wider use both in the scholarship I refer to, and among the subjects of my research.

6 Such prevalence of heterosexual couples partly reflects the belated legalization of same-sex marriage in the US, Europe and most parts of the globe. Researchers' focus on married couples (see for example Benson 1981; Osuji 2014; Roberts 2018), therefore, could not but exclude from purview unions which were denied access to this rite. 


\section{Methodology}

This article draws upon my multi-sited ethnographic research project exploring the implication of law in race making in contemporary Europe through the lens of the regulation of 'mixed (race) couples', which I define as intimate unions among partners whose bodies, heritage and/or nationality are socially ascribed to distinct racial categories. In line with much existing research (Bauer et al. 2012, p. 44; Törngren et al. 2019, p. 4), the mixed (race) couples I interviewed were constituted by a white partner, and a Black or mixed-race partner with African heritage (including diasporic), or who is (or was at birth) an African national. Research investigating the social construction of race and ethnicity inevitably face the risk of ontologizing rather than de-essentializing race (Gunaratnam 2003, pp. 32-33). Addressing this conundrum requires laying open the tensions underpinning the definition of the subject of my research.

Critical race theory and anthropological scholarship on 'interracial' or 'mixed' couples takes the regulation of their intimacy as an analytic of race relations and racism at a specific time and place (see for example Benson 1981; Childs 2008; Roberts 2018). However, the genealogy of these and cognate categories is rooted in the 'legacy of Anglo-European slavery and colonialism, which gave birth to the ominous idea of race in the first place' (Azoulay 2003, p. 234). Ambivalently, therefore, they simultaneously foreground and reproduce the racialized power relations shaping these intimate formations from without and from within. Nevertheless, the bogus that is race can only be challenged by exposing—rather than superseding, denying, or transcending—-the obnoxity of its real-life effects. ${ }^{7}$ Lacking a better term to convey the enduring legacy of Western colonialism and imperialism on the experiences of couples who traverse and are traversed by the boundaries of race, I thus opted for using the term 'mixed (race) couple'. ${ }^{8}$

My bracketing of race reflects the different ways in which this category circulates across my research sites. In England, the 'mixed' attribute always already implied 'race' - hence, the bracket signifies the quasi-redundancy of such specification. Outside of England-and particularly in Italy and in the Netherlands, where my other research sites are located-race was ostensibly suppressed (Lentin 2008). Partners generally identified themselves and one another through the category of nationality and described the mixedness of their union through the category of culture. Still, several scholars have convincingly shown that nation, culture (Balibar 1991a, 1991b) and place (Razack 2002) can each function as metonym of race. ${ }^{9}$ Here, therefore, the bracketing of race signifies its ambivalent status as an absent presence. Analogously, whenever introducing a white partner who did not identify racially I have signalled (white) between brackets with the sole purpose of making whiteness visible, refuting its privileged position as 'an unmarked marker of others' (Frankenberg 1993, p. 198).

My main research methods consisted of participant observation and open-ended interviews with mixed (race) couples and with individuals who either were or had until recently been in such a coupling relationship. I participated in a range of activities (e.g., public meetings, street protests, festivals) in which race and racism were debated and exposed, and others aiming at fostering 'conviviality' (Gilroy 2010, p. 12). Interviews were in depth and open ended, and lasted on average two hours. Questions explored partners dis/identification with the mixed (race) couple identity and their experiences of racial discrimination (if any) in different domains—and particularly housing, education, mobility, and

7 See for example Simon's discussion on the implications of Europe's 'failure' to import ethno-racial statistics (Simon 2017), and Gunaratnam's upholding of the usefulness of the UK census racial and ethnic categories (despite their approximation) in 'examining and in challenging inequalities, particularly in public services' (Gunaratnam 2003, p. 16).

8 Analogously, Peter Aspinall indicates that although the term 'mixed race' remains widely contested in academia due to the underlying ontological assumption of there being more than one 'race', it maintains currency in the absence of a term better able at reflecting subjects' self-identification (Aspinall 2009; see also Bauer et al. 2012, p. 5).

9 Note that these two categories often overlap, as cultural differences tend to be both essentialized (as nature) and territorialized within national (or continental) borders. Speaking of England in the 1970s, Susan Benson for example observed: 'For many of those entering interracial unions, as for the English in general, it proved difficult to escape the predisposition to associate culture with nature, and nature with the fact of colour.' (Benson 1981, p. 149). 
safety. The choice of the interview method lay with them: I interviewed partners jointly whenever they were willing to do so, and respectively separately or individually in case of impediments (e.g., conflicting work/care arrangements) or when only one partner wished to participate in the research. This flexibility reflected intertwined ethical and epistemological considerations. Allowing partners freely to decide the terms of their engagement ensured that participation into the research did not engender any tension between them, thereby prioritizing the 'do no harm' ethical imperative over methodological orthodoxy. Epistemologically, no methodological strategy holds the promise to elicit subjects' 'authentic' voice. Any interview is always a 'social situation' (Allan 1980, p. 205), and its irreconcilable contingency is further shaped by the interaction with the researcher (Taylor and Vocht 2011, p. 1577). Indeed, the latter's positionality influences not only what gets to be said, omitted or silenced by whom, but also the very patterns of participation in and exclusion from, the research. As a white European, heterosexual ciswoman, with a high cultural capital and degree of economic security, I am aware that my embodiment of the dominant race and sexuality, and my social class affected my fieldwork in multiple ways. ${ }^{10}$ While this complexity can never be resolved through single identity-based matching strategies (Gunaratnam 2003, p. 81), an intersectional approach (Collins 2015) demands a constant awareness and interrogation of one's position in the research, whereby the exercise of 'strong reflexivity' becomes a means to pursue a 'strong objectivity' (Harding 1993). Eventually, acknowledgement of the intrinsic partiality of both individual and joint narratives, and of how power relations play differently in different interview settings can, rather than impeding understanding, afford particularly insightful analysis.

I pursued my ethnographic research guided by an interest in exploring some of the multiple, complex and contingent ways in which (mainly) race, gender, class and sexuality inflected mixed (race) couples' everyday experiences. Rather than pursuing a sampling logic aiming at statistical representativeness, I followed a case study logic (Yin 2014), whereby interviews were conceived 'as not small-sample studies but multiple-case studies.' (Small 2009, p. 25) I approached potential interviewees through multiple routes carved during my participant observation, and by tapping into my professional and personal networks. Generally, subjects I met and/or interviewed offered to put me in contact with potential research participants. ${ }^{11}$ This vouching (Small 2009, p. 14) was particularly helpful and effective when performed by a Black or mixed-race woman, as it signaled my trustworthiness over, above and/or despite my race.

Consent to the interview was based on prospect participants' prior receipt of written information on the content, purpose and ethics of the research, followed, on the day of the interview, by their signature of a consent form before it started. ${ }^{12}$ I transcribed interviews verbatim, anonymized them, and sent transcripts to interviewees for their verification. Analysis proceeded through thematic coding using the qualitative software Atlas.ti.

In this paper, I specifically draw from data I collected in England between October 2018 and May 2019. During this time, I recorded approximately two hundred pages of field notes and twenty-six interviews to thirty-two people in total. Fieldwork concentrated on urban areas located in the South

10 For example, it made it harder to have interviews with Queer and Trans People of Color (QTPOC) living in families of choice, and with working-class mixed (race) couples.

11 From a quantitative, statistics-based research perspective, the snowballing technique (i.e., the practice of asking research participants to suggest prospect ones-see, e.g., Noy 2008) is seen as leading to a 'selection bias' vis-à-vis use of a randomized sample. Nevertheless, not only does the latter also embed a selection bias (due to non-response), but on a broader level, the sampling logic and language do not pertain to ethnographic research (Small 2009). Hence, " "bias" is the wrong term. What an in-depth interviewer with three dozen respondents faces is not a "bias" problem but a set of cases with particular characteristics that, rather than being 'controlled away', should be understood, developed, and incorporated into her understanding of the cases at hand.' (ibid., p. 14). In this article, I do so by grounding my interpretation work in the participant's biography, and in the (race, gender, social class and sexuality) position which they occupied at the time of the interview.

12 Before commencement the research received ethical clearance (24 May 2018) from the Ethics Committee of Juridical and Criminological Research of the Faculty of Law, VU Amsterdam. 
East and London regions, but it also encompassed activities in major cities in the South West (Bristol) and in the North (Liverpool, Manchester). Couples were prevalently heterosexual, with children born of their union, and partners' age spanned between 21 and 77 years. Most were married (or had divorced) and a few cohabited either de facto or as civil partners. The majority consisted of two British citizens either by birth or through the naturalization of the migrant partner. They prevalently enjoyed a middle-class existence, characterized by high levels of cultural and economic capital, while a few had high levels of the first and less of the latter. Politically, they all objected to Brexit. Such unanimity could be taken as a reflection of their social class and place of residence, as mainstream representations of the referendum result associated the Remain position to the highly educated and mobile middle classes, and to residents of London, the South East and major English cities. This interpretation, however, was subsequently found to be flawed. ${ }^{13}$ Although scant variation in interviewees' social class does not allow me to explore in depth whether and how it shaped their perceptions of Brexit, this finding nevertheless warns against the adoption of narrowly deterministic interpretations. In the next section, I describe the socio-political context within which my research unfolded by blending a review of relevant scholarship with my fieldwork observations.

\section{Melancholic British Whiteness}

I undertook fieldwork during part of the prolonged liminal period which followed the proclamation of the referendum result, as the country's withdrawal from the EU lingered like an increasingly vague promise attached to a constantly shifting calendar. ${ }^{14}$ Repeated governmental failures were accompanied by reports of intimidation, abuse and violence against $\mathrm{MPs},{ }^{15}$ and massive street demonstrations demanding a new referendum or an outright revocation of the withdrawal decision. ${ }^{16}$ Against the background of escalating violence against Black people, People of Color (POC) and immigrants (Home Office 2018; Paterson et al. 2018), the whiteness ostensibly shared by the social group most scapegoated for the 'excesses' of the EU freedom of movement regime (i.e., Eastern European nationals) and (the majority of) Leave voters was invoked to disavow racism. Yet, color sameness does not imply racial equality. Racism unamenable to color coding can be 'passed off as xenophobia, a 'natural' fear of strangers' (Sivanandan, quoted in Fekete 2001, p. 24) and, indeed, the racialization of Eastern European nationals occurs 'through the non-negotiable specification that they are immigrants.' (Gilroy 2006, p. 31) Rather than separate categories, therefore, race and immigration are deeply intertwined in the boundary-making politics of the nation (state), both affecting and reflecting changing boundaries of not/belonging to it.

Indeed, in the UK's post-WWII history, 'race and immigration have been connected policy agendas, and sometimes viewed as addressing almost the same set of issues.' (Khan and Weekes-Bernard 2015, p. 5). In the aftermath of the war and until the 1960s, successive governments encouraged immigration from the Commonwealth — which was predominantly black and brown—to meet the demand for cheap labor that would fuel reconstruction. With time, however, Commonwealth subjects became the object of increasing immigration control (Finch 2018, p. 1) until the landmark 1971 Immigration Act substantially

13 Dorling observed that 'most people who voted Leave lived in the south of England. Furthermore, of all those who voted for Leave, 59\% were in the middle classes (A, B, or C1).' (Dorling 2016). Nevertheless, the stigmatization of the working class implicit in their association with the pro-Brexit position, e.g., as less educated and more parochial, is consistent with sedimented 'white middle- and ruling-class attempts to pathologize and racialize them as an underclass.' (Garner 2007, p. 73).

14 A detailed timeline is available at: https://www.cer.eu/brexit-timeline. Accessed on 15 May 2020.

15 See for example https://www.theguardian.com/politics/2019/sep/28/threat-hostility-rise-female-mps-paula-sherriff-tracybrabin-boris-johnson-brexit and https://edition.cnn.com/2019/03/21/uk/brexit-related-attacks-mps-taxi-intl-gbr/index.html. Accessed on 5 May 2020.

16 Some of these were 'The People's Vote March for the Future' (20 October 2018) and the 'Put it to the People' march (23 March 2019), both held in London and with participation esteemed at several hundred thousand people. 
restricted access to the British islands to whites. ${ }^{17}$ The Act entered into force on 1 January 1973, and the simultaneous entry of the UK in the European Economic Community (EEC) ${ }^{18}$-a predominantly white space-could not but emphasize its underpinning racist logics. Indeed, as key British politicians publicly affirmed at the time (Carver 2016), postcolonial immigration was perceived as a danger for the biological and cultural reproduction (Yuval-Davis 1997) of the UK as a fundamentally white country. Growing miscegenation anxieties (Gilroy 1987, p. 80; Twine 2010, pp. 33-35) went hand in hand with heightened surveillance of marriage migration, which policing took intensely racialized and gendered connotations (Brah 1996; Turner 2015; Wray 2006). ${ }^{19}$ The 'stickiness' (Ahmed 2004, p. 120) of these miscegenation fears can be traced in the UK's enduringly stubborn 'reluctance to comply' with the extension of intra-EU mobility rights to nationals from outside of the European Economic Area (EEA) married to EU citizens (Carver 2016, p. 2761)—a finding which my later analysis will substantiate further.

The UK decision to withdraw from the EU has been widely interpreted (Burrell et al. 2019; Valluvan and Kalra 2019) as an expression of what Paul Gilroy defined as 'postcolonial melancholia':20 a longing to restore the Britain's lost imperial power and prestige- - both inextricably linked to whiteness-in conditions of disavowal of its racialized structural violence (Gilroy 2010, p. 82). Today, however, the racialization of immigration is no longer readily amenable to color coding, as most EU-27 citizens fall in the same racial category of the majority of the British population. Thus, the discursive reorganization of bodies that constitute versus those that dilute the nation unfolded through a series of 'metonymic slide[s]' (Ahmed 2004, p. 119), aligning EU citizens, Black Asian and minority ethnic (BAME) British citizens and refugees based on not being white and British. EU citizens' exercise of intra-EU mobility was relabeled as EU immigration (Favell and Barbulescu 2018). ${ }^{21}$ Historically color coded, the deployment of the immigration frame allowed the representation of EU citizens/immigrants as an incessant flow of destitute brown and black bodies in search of sanctuary (Valluvan and Kalra 2019 , p. 2394). ${ }^{22}$ Indeed, the wave of racist acts unleashed in the aftermath of the referendum against both EU citizens and British citizens and migrants who are classified and/or identify as Black or POC (see for example Burnett 2017, p. 86; Burrell et al. 2019, p. 10, written by Isakjee and Lorne) suggests that 'in [the perpetrators'] eyes, they were all outsiders' (Virdee and McGeever 2018, p. 1808).

While on fieldwork, my awareness of the UK's melancholic whiteness was intensified by the concomitant unfolding of the 'Windrush scandal'. The case concerns the impact of the government's 'Hostile Environment' policy on members of the so-called 'Windrush generation', i.e., Commonwealth citizens who settled in Britain before the entry into force of the 1971 Immigration Act. The policy instituted a 'system of routine citizen-on-citizen "papers, please" immigration checks as part of everyday life' (Yeo 2018b). ${ }^{23}$ Lacking a British passport, ${ }^{24}$ proof of lawful residency entailed tracing,

17 The Act introduced the concept of 'patriality', which restricted the right to enter, live and work in the British islands to British subjects who could demonstrate a genealogical connection by virtue of being born in the UK or having at least a parent or grandparent who had. At that time, this criteria effectively implied whiteness (Paul 1997).

18 .The Parliament's European Communities Act 1972 came into effect on 1 January 1973. The EEC is the precursor of the EU.

19 For example ' $[t]$ here were cases of Asian women arriving in Britain subjected to 'virginity tests' (Brah 1996, p. 38), which authorities used to assess the authenticity of the marriage they were about to enter (Wray 2006, p. 306).

20 In this writing, he also refers to it as 'post-imperial' melancholia.

21 In EU policy debates, EU nationals' migration within the EU is generally referred to as 'intra-EU mobility' and it is discussed separately from other forms of international migration involving 'third country nationals' (TCN), i.e., non-EU citizens https://www.understandfreemovement.eu/article/distinction-between-migration-and-mobility/. Accessed on 22 April 2020.

22 See for example the infamous 'Breaking point' poster: https://www.theguardian.com/politics/2016/jun/16/nigel-faragedefends-ukip-breaking-point-poster-queue-of-migrants. Accessed on 25 April 2020.

23 Announced in 2012, the policy 'tasked the NHS, landlords, banks, employers and many others with enforcing immigration controls.' https://www.jcwi.org.uk/windrush-scandal-explained. Accessed on 21 May 2020.

24 Partly, this was due to the fact that many 'arrived as children on their parents' passports, and that the Home Office destroyed thousands of landing cards and other records.' https://www.jcwi.org.uk/windrush-scandal-explained. Moreover, Section 3(8) of the Immigration Act 1971 placed the burden of proof on individuals: 'When any question arises under this Act whether or not a person is a British citizen [or otherwise has the right of abode] ... it shall lie on the person asserting it to prove that he [sic] is.' (UK Government 1971). 
collecting and displaying elaborate 'paper trails' (Tuckett 2019), consistency of which was (and remains) unachievable to many. ${ }^{25}$ As a result, many suddenly lost homes, jobs, health care, pensions, and social security, while some experienced immigration detention, deportation, and were denied entry (Home Affairs Committee 2018). Epitomizing both the instability of the boundaries of the nation (state) and the contested nature of belonging (to the UK), the echoes of the Windrush scandal were, as I will show, clearly discernible in the narratives of narratives of the Black and mixed-race partners that I interviewed.

In the following sections, I delve into the analysis of four interviews with mixed (race) couples. Rather than constituting a representative, average experience- the investigation of which belongs to disciplinary traditions and methodologies other than ethnography (Small 2009, p. 25)-these offer a range of cases illuminating the complex and always situated ways in which race inflects partners' perceptions of Brexit, and interplays with other salient characteristics, and notably, here, citizenship/migration status and sexuality. In doing so, my aim is to contribute fostering an intersectional analysis of the hierarchies of privilege and disadvantage that mediate people's experiences of Brexit and more broadly, of their sense of (un)belonging (to the UK).

The rest of the article is organized as follows. In Section 4, I foreground how partners alternatively perceived Brexit as a historical rupture or as an event in a continuum; and as a loss of entitlement to mobility in space, or of the legitimacy of permanence in place. In Section 5, I discuss how race and citizenship/migration status mediated partners' trust (or lack thereof) in the documents enshrining their right to reside in post-Brexit UK. In Section 6, I focus on the interplay between race and sexuality by looking at (same-sex) partners' perception of the temporality of the risks of heightened violence which they associated with Brexit.

\section{Ordinariness of Racism}

I interviewed Stephanie and Nick in their house in Brighton, where they lived with their children. ${ }^{26}$ Born approximately fifty years ago, they have spent fifteen as a married couple. Both relayed that whiteness structured their upbringing deeply, albeit in markedly different ways. 'I come from a white middle-class background, and I lived in a predominantly white town' recounted Nick-his troubled sigh expressing awareness of his privileged race and class position. A Black British woman of Afro-Caribbean heritage, Stephanie also grew up in 'an environment which was actually very, very white', but to her this meant early exposure to systemic racial discrimination. ${ }^{27}$

Both partners considered the referendum result as inextricable from racism. For Nick, Brexit 'has really broke home the underlying racism that still exists although we proclaim to be a very non-racist, open, accepting society.' For Stephanie, immigrant scapegoating was a smokescreen concealing the government's responsibility for increasing pauperization: 'I think that the underbelly has spoken, you know? People who are disenfranchised. And they are disfranchised not because of migration, they have been left behind because of the welfare state over here.' Their consensus on the present, however, did not level out the different role which race played in their subjectification. This divergence became particularly apparent to me in their responses to whether and how Brexit impacted on their lives, foregrounding a particular relationship between race, place and space.

Nick described Brexit as a rupture, and a world-changing event. Born just a handful of years before the UK joined the EEC [then EU], he relayed feeling swindled and shattered at the prospect of no longer being part of it. 'They are taking away from me part of my identity, which is European' he said. A well-travelled man who has spent several years working abroad, Nick's identification with

25 They had to produce, in front of the Home Office, at least 'one official document from every year they had lived' in the country. https://www.jcwi.org.uk/windrush-scandal-explained. Accessed on 21 May 2020.

26 I interviewed them both on 26 April 2019, but separately.

27 For example, speaking of her own and her brother's early years at school, she said that teachers 'did everything they could to suppress you.' 
Europe arguably reflects the strong association of European citizenship with the exercise of intra-EU mobility (Miller 2012, pp. 8, 10). More deeply, it mirrors the ways in which the whiteness of his body seamlessly maps onto the whiteness of Europe as a 'racial formation' (Omi and Winant 1994), engendering a peculiarly comfortable experience of mobility in space (Ahmed 2007). The loss he anticipates, I contend, expresses his 'white habitus' (Bonilla-Silva 2018, p. 121), and specifically whites' entitlement to moving in space not just unbounded by race, but in virtue thereof. ${ }^{28}$ On the other hand, for Stephanie, Brexit did not appear to be particularly impactful in itself, but required contextualizing within the broader history of the UK's regulation of immigration, since the Windrush generation onwards. In her words, the pro-Brexit camp expressed a melancholic attachment to 'a world which never existed before there was any migration - because there has always been some level of migration' she said smiling sardonically, her complicit eyes in mine underlying my own migrant condition, 'and you decide that it's because of those migrants that we don't have work. So first of all, it was the Blacks and then it was the Asians and now it's the Eastern Europeans ...'

Stephanie's words suggest that notwithstanding cyclical changes in the group of most discriminated Other, the systemic character of Britain's racialized policies of exclusion (Burrell et al. 2019, p. 6, written by Burrell and Hopkins; Virdee and McGeever 2018, p. 1803) remains unchanged. Her analysis echoed in the words of Alesha, also a Black British woman of Afro-Caribbean heritage. In her late thirties, she is married to Giovanni-an Italian (white) man of her age. ${ }^{29}$ At the referendum, the greater London borough where they live expressed a majority pro-Leave, 'which was a real disappointment', she said. Tenderly rocking their toddler side to side, Alesha spoke passionately about the reasons of her opposition. 'By the time the referendum happened, so much of the rhetoric was actually around immigration and it became racist, and it had become toxic', she recalled,

it became about, "Well we have too many foreigners here." And it's like, we've been hearing this stuff every time there's a general election, since we really started to have mass immigration, the post-war years, we have this all the time.

In Alesha's words, the political rhetoric surrounding the referendum replicated that circulating since the Windrush generation, of which she is herself a descendent. Both her parents indeed migrated to the UK

because the British Government invited people-so there was less work back at home, and opportunities here. So, they were able to come, the restrictions hadn't started yet on immigration, and as my mum will always point out, she came here as-I think she was a British subject, not a British citizen but she had a British passport, which obviously was the key thing. ${ }^{30}$

Awareness of the racial discrimination that her parents endured, compounded by her own experiences of racism, informed her perception of Brexit as an ordinary—rather than exceptional—spike. Alesha was indeed particularly disappointed with relative of hers who, in voting Leave, ${ }^{31}$ failed to recognize that the politicians barking against EU immigration 'are actually the same people who would like [us] to

28 Drawing on Bourdieu's concept of 'habitus' (Bourdieu 1984), Bonilla-Silva defined 'white habitus', one which 'creates and conditions [whites'] views, cognitions, and even sense of beauty and, more importantly, fosters a sense of racial solidarity.' (Bonilla-Silva 2018, p. 140). Here, I expand on this notion by suggesting to include also whites' perception of inalienable entitlement to unrestrained mobility in space and permanence in place.

29 I interviewed Alesha and her husband Giovanni separately, respectively, on 2 May and 15 April 2019.

30 Possession of this document allowed the mother to demonstrate the lawfulness of her presence in Britain under the conditions established by the Hostile Environment policy (see under 'Melancholic British whiteness').

31 The British Election Study found that ' $29 \%$ of Black adults and 32\% of Asian adults voted Leave' (Swales 2016, p. 7). A public opinion report observed that Black Asian and Minority Ethnic (BAME) people who voted Leave 'raised concerns about immigration, particularly Eastern European, which they felt increased pressures on public services and strained community relations.' (Begum 2018, p. 10). 
leave as well.' Her words echo the findings of a recent report on minority ethnic and migrant groups' views on immigration, which registered their almost unanimous opinion 'that the immigration debate was about them, even among those born in Britain.' (Khan and Weekes-Bernard 2015, p. 33). Hence, rather than the loss of one's privileged mobility in space-which black and minority ethnic people enjoy less of (ibid., p. 34) - in Alesha's narrative, Brexit appears to be a further attempt at undermining British Black and POC's legitimate permanence in place.

A first-generation migrant with a long-term project of returning to Italy, bringing his family along, her husband Giovanni was ostensibly far less upset by Brexit. Quite dispassionately, he recounted having 'taken [British] citizenship immediately after the referendum'. Giovanni's behavior was widespread among the EU citizens I encountered and/or interviewed who fulfilled the relevant criteria-including the capacity to afford the high costs of the application. ${ }^{32}$ The sheer volume of this trend (Fernandez-Reino and Sumption 2020, p. 7; Sigona and Godin 2019, p. 4; Yeo 2018a) reflects the changing structure of the incentives shaping the relationship between EU nationals and the UK government. ${ }^{33}$ Some scholars interpreted it as 'a form of defensive citizenship' engendered by a political climate 'hostile to foreigners' (Sigona and Godin 2019, p. 8). Significantly, many EU families relayed fear of 'becoming the new Windrush generation' (Sigona and Godin 2019, p. 7)—a finding which suggests that Brexit and the Windrush scandal are different expressions of the same will to eject not-white and British subjects from the body of the nation.

\section{Mistrust in the UK State}

The enduring legacy of European colonialism on regimes of racialized mobility and stuckness (Achiume 2019) emerged vividly in the narratives of mixed (race) couples constituted by an EU-27 and a third country national, manifesting particularly in partners' different perceptions of the consequences of Brexit on their right to reside in the UK.

Gianluca and Kaylah met approximately twenty years ago as postgraduate students in Belgium. Since then, they weaved their relationship on the move, across multiple localities, while building their career pathways. ${ }^{34}$ Eventually, both settled in the UK through independent albeit similarly work-related routes. For Gianluca, a (white) Italian citizen, these moves were unremarkably smooth, expressing his intra-EU mobility rights. A Trinidadian citizen, Kaylah's experiences were radically at odds with her partner's, and her capacity to move was always pendant upon obtainment of temporary, purpose- and place-based visas, which criteria could be so narrow as to entail in-country limitations, as she recounted:

They introduced the scheme [Fresh Talent-Working in Scotland Scheme] around the time of my PhD and the idea was to attract students to stay in Scotland. The thing is that there are not many jobs in Scotland and you know, if you really wanted to develop your career, you would probably think about moving to London. So, I didn't stay in Scotland. I moved to London and that is when the visa issues started [ ... ] They [her employers] applied for a work permit, but when I was applying for my residency, they rejected it, because they said I should have actually stayed in Scotland. I should not have been working in London for more than a year or something like that.

With a letter from the Home Office stating that she had 'twenty-eight days to leave the country', Kaylah and Gianluca eventually decided to get 'lawyers involved'. They appealed, and won the case

32 In April 2018 the naturalization fee was increased to $£ 1330$ per person: https://www.gov.uk/government/publications/visaregulations-revised-table/home-office-immigration-and-nationality-fees-2018. Accessed on 27 May 2020.

33 Before the UK decided to leave the EU, EU nationals' legal rights to settlement in the UK were defined by the EU Citizenship Directive. Hence, they did not have strong incentives to enter into a 'formal path to permanent settlement and naturalization' (Moreh et al. 2020, p. 2).

34 Joint interview, 3 May 2019. 
in court. However, the fears and sense of precariousness engendered by this experience motivated them to shift the grounds of Kaylah's permanence in the UK from an independent work-based visa to a family-based one:

So, because I was with Gianluca for so long, I applied as his partner, even if we weren't married then. [ ... ] Unfortunately, I had to wait two and a half years to get that and during that time, I could not leave the country. So that was the worst, absolute worst time of my life. It was horrible.

Kaylah's words relay the vividness of the pain and rage she felt throughout this experience and particularly during the prolonged limbo she was thrown into. Gianluca, however, downplayed the unfairness of the treatment she was reserved. In response to my question why the process took this long, he explained that:

This was not a UK document, [ ... ] it was an EU permit that they were accepting, so to apply for that, she had to send the passport to the Home Office for all the time it needed, which was six months or so, or a year maybe.

His words suggest his perception of the incident as an ordinary, 'natural' expression of sovereign power. For Kaylah, however, race-and thus inequality — was the explanation. 'They kept my passport for two and a half years' she repeated vehemently. 'If you are not European, they treat you differently, obviously', she concluded-her statement substantiating the peculiarly stubborn obstacles facing non-EEA citizens married to EU nationals (Carver 2016, p. 2761).

Spouses' different perceptions of what role, if any, race had in the workings of the UK immigration system mirrored onto their Brexit narratives. Confident in the certainty of their entitlement to stay based on his possession of a Permanent Residence Card (PRC), Gianluca held the position that Brexit 'is not really affecting us'. Kaylah, however, unrelentingly disagreed with his view. 'It has just made me run to apply for the passport!' she exclaimed, not without a touch of sarcasm. They continued:

Gianluca: As I said before, you did not have to.

Kaylah: I did not have to, but I did ...

Gianluca: Yeah, you did because you wanted to but you didn't have to ... it had nothing to do with Brexit.

Kaylah: I got a bit nervous because I don't know if they will change the regulations again.

Gianluca: Yeah, but they cannot change ... I had it too. The only thing I did, I applied ...

In pronouncing these last words, Gianluca pointed with his head towards something behind my back and I asked, what to. It was the drawer where he kept his PRC:

It is just this [document]. Just this thing that cost ... it cost one hundred pounds. So, I never had to do this [before Brexit]. Some people did it, straight away. And I didn't have to do it ... I do not have to do it right now [either], but I just decided to do it. So, this basically allows me to work forever in the UK without any visa. Or just live ... even if I just want to live here. For example, another EU citizen, after Brexit, [ ... ] if he does not have that, he won't be able to stay.

Gianluca's serene confidence in the long-term validity of his newly acquired residence title arguably betrays his white habitus to the privileges tethered to his national and European citizenship-privileges materialized here, as well as in Nick's interview, in their spatial mobility aspect. Conversely, for a person, like Kaylah, who is painfully familiar with the shifting requirements of immigration regimes, this trust was nowhere to be found. She continued: 
So, I will tell you another reason I applied for the passport. Because the residence permit, I had, was based off of Gianluca being an EU citizen. Now if the UK Brexited, my visa wouldn't apply, my permit would not apply anymore. So, I said, 'What is the point of reapplying for this when I can apply for my passport?' [ ... ] So, I did it before Brexit [ ... ] in case the rules changed. And I mean, when Zachary [their son] was born, I immediately applied for a British passport for him. Gianluca applied for the Italian passport and he said, 'Why did you apply for the British passport?' 'I do not know. The regulations might change. I have no idea.' So that is why I did it, and I am glad I did it because maybe he might have had some issues now. I don't know, right?

Kaylah's anxious, almost compulsive production of papers certainly betrays both their economic privilege and her financial autonomy. Yet, I suggest to read her ostensible overreaction as a symptom of the racialized affective economy of (un)belonging revealed by Brexit and the Windrush scandal. Anthropologist Yael Navaro-Yashin discussed fantasy and fiction as constitutive elements of our social and political realities. Politics, she suggested, maintains a 'phantasmatic aspect' (Navaro-Yashin 2007, p. 80), and so do the documents through which the state distributes titles of not/belonging to it. Her concept of documents' 'make-believe' quality (Navaro-Yashin 2007, p. 82) foregrounds that their agency is contingent upon subjects' belief in them. A Trinidadian national, Kaylah carried an embodied, intimate knowledge of the UK state's fickle boundaries of inclusion of not-white and British subjects into the body of the nation. Her document-stockpiling, I thus suggest, is a paradoxical reaction to her loss of belief in their value-as none could placate her fears and anxieties-which hints, more deeply, at her mistrust in the issuing state.

'Yeah, this is just precautionary, but we don't think we are at risk ... because we have been here for so long' continued Gianluca. The ostensible refusal to concede to his wife's fears expresses, I contend, his white habitus, taking the shape of a deep-seated perception, and lived experience, of inalienable entitlement to permanence in place and mobility in space. In turn, this translates into a 'natural' belief in the stable, durable value of the documents enshrining this white privilege. 'I do think I am at risk' said Kaylah turning her head to look at him. He, however, turned to me-as if searching for complicity and understanding from a likewise (white) EU national. 'I don't think Brexit will make a difference in terms of-' he tentatively said. 'Find out!' exclaimed Kaylah interrupting him, and laughing with the defiance of a worldly black migrant. 'I have boxes of documents there just in case they ask me' she added, pointing at some shelves. When looking back one more time at their sitting room before leaving, I felt how the apparent comfort of their home was premised upon discretely nestled layers of treasured documents of an intrinsically unstable value.

\section{Heightened Alertness}

Mistrust in the durability of the inclusion within the body of the nation (state) also emerged in the narratives of the same-sex mixed (race) couples I interviewed, showing how partners' differently racialized subjectivities intersect with their experience of sexuality-based discrimination.

I interviewed George and Philippe in their cozy house in London, located in a neighborhood which recent gentrification had transformed its migrant and interracial character into a predominantly white middle-class area. ${ }^{35}$ They met approximately fifteen years ago and a few years later they bonded in a civil partnership. When I asked why they opted for this rite, George relayed that back then 'this was the only choice' available to same-sex couples wishing to formalize their union in front of the state. ${ }^{36}$

35 Philippe recalled that there used to be 'a lot of mixed couples, because there were a lot of Irish people married into the black Caribbean community.'

36 The Civil Partnership Act came into nationwide effect on 5 December 2005. The legalization of same-sex marriage took place several years after, and at different times in different parts of the UK. In England and Wales it was legalized in March 2014. 
In their encounter with England, both partners experienced racism and homophobia intertwined. A white British man in his mid-50s, George spent part of his childhood in the Caribbean growing up 'a bit outside of the ... norms of English society.' Its return to it, however, was particularly harsh. 'England in the 70s was really openly racist' he said, with Philippe next to him nodding in agreement. Speaking of his time at a prep school, he recalled that if I said I had black friends, then ... I would get insulted for that'. Growing up, awareness of his homosexuality translated into a 'sense [that] there's always a bit of danger around, you have to be careful'. Back then, in fact, the decriminalization of homosexuality was not only partial, ${ }^{37}$ but also situated within a persistently homophobic larger political field, ${ }^{38}$ contributing to gay men's experience of unsafety in public space. George explained: '[W] hen I first moved to London-which was after university, in 1984-it was pretty normal for gay people to get beaten up then, it wasn't considered remarkable.' '[You develop] a sense of survival' added Philippe. A few years younger than George, Philippe was born in Saint Lucia, which he left at a young age partly for work reasons, and partly to know the world outside of the island, as he explained:

I think a lot of Saint Lucians, especially my generation, we tend to leave Saint Lucia for periods of time. So, the idea would be that you would move out of Saint Lucia to work or to study. Some people go back, some people form relationships and then stay behind and stay in Europe. But I think also, growing up as a gay person in the Caribbean, even if at the time I was in Saint Lucia, Saint Lucia was still quite open and accepting, you still feel like you need to explore the rest of the world because the gay community is so small in the Caribbean.

Once in England, however, Philippe did not find the openness he sought. It was now George's turn to nod in agreement as Philippe recounted:

I remember in my early-20s, on the gay scene in London, you always came across racism within the gay scene. Always either, the first thing people would say, [was] "Oh, you are black, you are either looking for a rich husband" or "you're black, you can't afford anything."

Although Philippe said that 'now, because there is far more discussion about racism within the gay community, you find it far less so than it was', he also spoke of continuing assumptions about his own, and more broadly, the non-white partner's economic dependence on the white partner-which he termed as 'sponging off'. The proud posture he took in enunciating this expression relayed his vivid pain for the underlying assumptions of black people's inferiority and immorality. It also suggested that his experience of racism was not a relic of the past.

It was the eve of the EU Parliament elections when I interviewed them, and when I asked whether they intended to vote, they burst into laughter. 'Oh, we've already voted!' Philippe said. ${ }^{39}$ Both strongly objected to leaving the EU and relayed that the Leave victory had thrown them in a heightened state of alertness. The weight of their differently racialized subjectivities, however, filtered through their narration of the temporality of the risks they associated with Brexit. In response to my question on whether and how the latter impacted their lives, George was the first to take the floor responding:

Well, no, not exactly. But I think you know that when hate speech is on the rise and legitimized by certain politicians, that might be directed at the EU or immigrants one minute, but you can be damn sure it's going to come around to gays next!

37 In 1967, the Sexual Offences Act decriminalized in England and Wales homosexual acts in private between two men aged 21 and above (UK Government 1967). The equalization of the age of consent with that for heterosexual and female same-sex happened only in 2000, with the Sexual Offences (Amedment) Act (Kollman and Waites 2011, p. 189).

38 For example, the Local Government Act 1988, Section 28 ('Prohibition on promoting homosexuality by teaching or by publishing material'), established that local authorities 'shall not (a) intentionally promote homosexuality or publish material with the intention of promoting homosexuality; (b) promote the teaching in any maintained school of the acceptability of homosexuality as a pretended family relationship.' (UK Government 1988). This legislation was accompanied by media campaigns indicting and outing homosexual teachers (and also other public workers) for their role and position supposedly constituted a danger for the 'healthy' reproduction of the nation (Moran and Skeggs 2004, p. 7).

39 They voted by post. 
A white British citizen, George's words suggest that he did not feel that Brexit endangered him now. Nevertheless, the slippery slope metaphor he uses suggest not only his entwined understanding of racism and homophobia, but also his deeper mistrust in the durability of state protection of non-normative sexual subjectivities. Nodding next to him all along, Philippe waited for George's nervous laughter to fade away before stepping in:

Yeah, but also, I think whenever there is even a hint of hate speech or segregation, or whatever, I think you pick it up much quicker and you analyze it much quicker, and think, "OK, this person is really trying to erase ..."

For a person, like Philippe, whose race never ceased to be a ground of discrimination, Brexit appears less a gloomy omen of a lingering threat and more a catalyst and magnifier of already existing patterns of racialized violence- - the intensification and radicalization of which, now, feel more dangerously plausible. Against this background, the EU emerged as a protective umbrella which they longed to hold on to. For George, exiting it was tantamount to endangering the peace it brought upon intra-European relations:

I suppose I am very aware of the Second World War because my father was always very ... he talked about it a lot, he is a historian and he is interested in those things. He also lost both of his brothers in the war so, emotionally, it was a very present thing. And ... so that sense of how easily things can degenerate into a terrible conflict is something I've always been made aware of as I grew up. And ... to me, it's terrifying to see the irresponsibility of people like Trump and Farage.

The dangers which Philippe anticipated in leaving the EU, however, were more a reflection of the grip of race on his life. 'I think being in the EU creates a more inclusive society and community because [ ... ] it's a big melting pot of race and culture, being part of the $\mathrm{EU}^{\prime}$, he said. Philippe's arguably romanticized view is amply contradicted by reports documenting the extent and virulence of racism in Europe (European Union Agency for Fundamental Rights 2018; Nwabuzo 2019). Rather than self-delusion, however, ${ }^{40}$ I take his words to signal an aspiration to breathe higher and above the racism which Brexit broke open in the place he made home. In this sense, therefore, membership in the EU acquires a defensive value against the rising ethno-nationalist tide (Achiume 2018).

\section{Conclusions}

In this article, I have discussed the racialized affective economy of (un)belonging which Brexit revealed by exploring how British and mixed-migration status, mixed (race) couples narrated its impact on their lives. I have paid particular attention to showing how partners' perceptions were mediated by race, citizenship/migration status and sexuality.

Couples shared a general understanding of Brexit as an expression of the UK's unresolved structural racism. Race, however, inflected partners' different perception of what leaving the EU meant to them. For white partners, Brexit appeared to mainly endanger their entitlement to unrestrained movement in space and unquestioned presence and permanence in place-perceptions which, I have contended, express their white habitus. Indeed, these freedoms which they feared losing are inextricably entangled with their own and Europe's whiteness. Whereas British citizens could not but contemplate the sight of their spatial entitlement crumbling in front of their eyes, EU nationals enacted counterstrategies to legally anchor themselves to the UK-strategies which, in the cases here discussed, relied upon and expressed their economic privilege.

40 Moreover, Hubbard notes that many of the rights which 'lesbian, gay and bisexually-identified individuals' have had recognized in the UK since the 2000s 'have been secured with reference to citizenships negotiated at the EU level, with the UK incorporating the European Convention on Human Rights (1950) in the UK Human Rights Act 1998 (UK Government 1998).' (Hubbard 2013, p. 225). 
Rather than foreshadowing a historical and biographical rupture in one's experience of space and race as virtuously, mutually constitutive, for Black and mixed-race partners, Brexit rather appeared as just another spike in the country's structural discrimination of non-white and British subjects. This finding echoes Benson and Lewis' in their research on POC living in the EU-27, for whom Brexit was 'more of the same: lifelong experiences of structural, institutional and everyday racism' (Benson and Lewis 2019, p. 2225). Rather than a loss of mobility in space, Black and mixed-race partners perceived Brexit as a further challenge to their presence and permanence in place, i.e., on UK soil, as Black British citizens. In their words, the racialized affectivities of (un)belonging unleashed by Brexit tethered to the Windrush scandal, and vice versa.

I have also suggested that, for subjects carrying an embodied memory of British colonial rule and/or of sexuality-based discrimination, the concomitance of the pro-Brexit vote and the Windrush scandal exacerbated awareness of the fickle boundaries of national inclusion drawn by the UK state, engendering mistrust and alertness. Against white European citizens' habitus to their inalienable residence in a place of their choice, Kaylah's anxious collection of state documents betrays her embodied knowledge of the relative ease with which she can be displaced from the place she had made home. I have also shown how race differently inflected the temporality of the dangers which same-sex partners associated Brexit with. Whereas for George, a white British man, Brexit represented a move down a slippery slope-one after which non-heteronormative sexualities would be persecuted again—for a Black man and first-generation migrant like Philippe, Brexit signaled the mainstreaming of a particularly obnoxious form of racism, the consequences of which he viscerally felt already. Notwithstanding the different salience of race and sexuality in their Brexit narratives, however, both looked up to membership of the EU as a protective cloak-one whose removal would leave them in a more threateningly ethno-national space.

Funding: This research is part of the project 'Regulating Mixed Intimacies in Europe (EUROMIX)', which has received funding from the European Research Council (ERC) under the European Union's Horizon 2020 Research and Innovation programme under grant agreement No 725238.

Acknowledgments: I would like to express my heartfelt thanks to the women, men and non-binary subjects I encountered and/or interviewed throughout my research for their trust, and for sharing with me their experiences, views, and reflections. I also thank the PI of the EUROMIX project, Betty de Hart, the Editor of the Special Issue, Ginger Frost, and the anonymous peer reviewers, for their constructive criticisms on earlier drafts of this text.

Conflicts of Interest: The author declares no conflict of interest. The funders had no role in the design of the study; in the collection, analyses, or interpretation of data; in the writing of the manuscript, or in the decision to publish the results.

\section{References}

Achiume, Tendayi. 2018. Report of the Special Rapporteur on Contemporary Forms of Racism, Racial Discrimination, Xenophobia and Related Intolerance. A/HRC/38/52. New York: United Nations General Assembly.

Achiume, Tendayi. 2019. Migration as Decolonization. Stanford Law Review 71: 1509-74.

Ahmed, Sara. 2004. Affective Economies. Social Text 22: 117-39. [CrossRef]

Ahmed, Sara. 2007. A phenomenology of whiteness. Feminist Theory 8: 149-68. [CrossRef]

Allan, Graham. 1980. A Note on Interviewing Spouses Together. Journal of Marriage and Family 42: $205-10$. [CrossRef]

Aspinall, Peter J. 2009. "Mixed Race", "Mixed Origins" or What? Generic Terminology for the Multiple Racial/Ethnic Group Population. Anthropology Today 25: 3-8. [CrossRef]

Azoulay, Katya Gibel. 2003. Review of Rethinking "Mixed Race" [Review of Review of Rethinking "Mixed Race," by D. Parker \& M. Song]. Research in African Literatures 34: 233-35.

Balibar, Étienne. 1991a. Is there a "Neo-Racism"? In Race, Nation, Class: Ambiguous Identities. Edited by Étienne Balibar and Immanuel Maurice Wallerstein. London: Verso, pp. 17-28.

Balibar, Étienne. 1991b. The Nation Form: History and Ideology. In Race, Nation, Class: Ambiguous Identities. Edited by Étienne Balibar and Immanuel Maurice Wallerstein. London: Verso, pp. 86-106. 
Bauer, Elaine, Catherine Houlston, Lester Coleman, and Rosalind Edwards. 2012. An Academic and Voluntary Sector Collaboration to Facilitate Relationship Support for "Mixed" Couples and Families: Project Report. No. 31; Families \& Social Capital Research Group Working Paper. London: London South Bank University.

Begum, Neema. 2018. The UK in a Changing Europe. Edited by Anand Menon. London: The UK in a Changing Europe, pp. 9-11.

Benson, Susan. 1981. Ambiguous Ethnicity: Interracial Families in London. Cambridge: Cambridge University Press. Benson, Michaela. 2019. FOCUS: Brexit and rethinking the British in Europe. Discover Society. Available online: https://discoversociety.org/2019/02/06/focus-brexit-and-rethinking-the-british-in-europe/ (accessed on 24 February 2020).

Benson, Michaela, and Chantelle Lewis. 2019. Brexit, British People of Colour in the EU-27 and everyday racism in Britain and Europe. Ethnic and Racial Studies 42: 2211-28. [CrossRef]

Berlant, Lauren. 2016. The commons: Infrastructures for troubling times. Environment and Planning D: Society and Space 34: 393-419. [CrossRef]

Bonilla-Silva, Eduardo. 2018. Racism without Racists: Color-Blind Racism and the Persistence of Racial Inequality in America, 15th ed. Lanham: Rowman \& Littlefield.

Bourdieu, Pierre. 1984. Distinction: A Social Critique of the Judgement of Taste. London: Routledge \& Kegan Paul. Brah, Avtar. 1996. Cartographies of Diaspora: Contesting Identities. London: Routledge.

Burnett, Jon. 2017. Racial violence and the Brexit state. Race E Class 58: 85-97.

Burrell, Kathy, Peter Hopkins, Arshad Isakjee, Colin Lorne, Caroline Nagel, Robin Finlay, Anoop Nayak, Matthew C. Benwell, Raksha Pande, Michael Richardson, and et al. 2019. Brexit, race and migration. Environment and Planning C: Politics and Space 37: 3-40. [CrossRef]

Carver, Natasha. 2016. 'For her protection and benefit': The regulation of marriage-related migration to the UK. Ethnic and Racial Studies 39: 2758-76. [CrossRef]

Childs, Erica. 2008. Listening to the Interracial Canary: Contemporary Views on Interracial Relationships among Blacks and Whites. Fordham Law Review 76: 2771.

Collins, Patricia Hill. 2015. Intersectionality's Definitional Dilemmas. Annual Review of Sociology 41: 1-20. [CrossRef]

Dennison, James, and Andrew Geddes. 2018. Brexit and the perils of 'Europeanised' migration. Journal of European Public Policy 25: 1137-53. [CrossRef]

Dorling, Danny. 2016. Brexit: The decision of a divided country. BMJ, 354. [CrossRef]

European Convention on Human Rights. 1950. Council of Europe, European Convention for the Protection of Human Rights and Fundamental Freedoms, as amended by Protocols Nos. 11 and 14, 4 November 1950, ETS 5. Available online: https://www.echr.coe.int/Documents/Convention_ENG.pdf (accessed on 15 June 2020).

European Union Agency for Fundamental Rights. 2018. Second European Union Minorities and Discrimination Survey_Being Black in the EU. [EU_MIDIS II]. Vienna: European Union Agency for Fundamental Rights.

Favell, Adrian, and Roxana Barbulescu. 2018. Brexit, 'Immigration' and Anti-Discrimination. In The Routledge Handbook of the Politics of Brexit. Edited by Patrick Diamond, Peter Nedergaard, Ben Rosamond and Christian Lequesne. London and New York: Routledge, Taylor \& Francis Group, pp. 118-33.

Fekete, Liz. 2001. The Emergence of Xeno-Racism. Race E Class 43: 23-40.

Fernandez-Reino, Mariña, and Madeleine Sumption. 2020. Citizenship and Naturalisation for Migrants in the UK. Briefing 6th Revision. Oxford: The Migration Observatory-University of Oxford. Available online: https://migrationobservatory.ox.ac.uk/wp-content/uploads/2020/03/Briefing-Citizenshipand-naturalisation-for-migrants-in-the-UK.pdf (accessed on 2 April 2020).

Finch, Alexander. 2018. Understanding 'Windrush': Legal Background and Practical Issues. New York: Fragomen LLP. Available online: http://appgmigration.org.uk/wp-content/uploads/2018/05/Windrush-generation-briefingFragomen-LLP.pdf (accessed on 10 June 2020).

Frankenberg, Ruth. 1993. White Women, Race Matters: The Social Construction of Whiteness. London: Routledge. Garner, Steve. 2007. Whiteness: An introduction. London: Routledge.

Gilroy, Paul. 1987. There Ain't No Black in the Union Jack: The Cultural Politics of Race and Nation. London: Hutchinson.

Gilroy, Paul. 2006. Multiculture in times of war: An inaugural lecture given at the London School of Economics. Critical Quarterly 48: 27-45. [CrossRef]

Gilroy, Paul. 2010. Postcolonial Melancholia. New York: Columbia University Press. 
Grütters, Carolus, Elspeth Guild, Paul Minderhoud, Ricky van Oers, and Tineke Strik. 2018. Brexit and Migration. Brussels: Policy Department for Citizen's Rights and Constitutional Affairs-Directorate General for Internal Policies of the Union. Available online: https:/www.europarl.europa.eu/RegData/etudes/STUD/2018/608835/ IPOL_STU(2018)608835_EN.pdf (accessed on 4 March 2020).

Gunaratnam, Yasmin. 2003. Researching Race and Ethnicity: Methods, Knowledge, and Power. London: Sage Publications.

Harding, Sandra. 1993. Rethinking Standpoint Theory: What is "strong objectivity"? In Feminist Epistemologies. Edited by Linda Alcoff and Elizabeth Patter. New York: Routledge, pp. 49-82.

Haritaworn, Jin. 2012. The Biopolitics of Mixing: Thai Multiracialities and Haunted Ascendancies. Farnham: Ashgate.

Home Affairs Committee. 2018. The Windrush Generation. No. 6. London: Home Affairs Committee. Available online: https://publications.parliament.uk/pa/cm201719/cmselect/cmhaff/990/99002.htm (accessed on 11 March 2020).

Home Office. 2018. Hate Crime, England and Wales 2017/18; No. 20; Statistical Bulletin; London: Home Office. Available online: https://assets.publishing.service.gov.uk/government/uploads/system/uploads/attachment_ data/file/748598/hate-crime-1718-hosb2018.pdf (accessed on 7 October 2019).

Hubbard, Phil. 2013. Kissing is not a universal right: Sexuality, law and the scales of citizenship. Geoforum 49: 224-32. [CrossRef]

Khan, Omar, and Debbie Weekes-Bernard. 2015. This Is Still about Us: Why Ethnic Minorities See Immigration Differently. Runnymede Report on Race and Immigration. London: Runnymede.

Kollman, Kelly, and Matthew Waites. 2011. United Kingdom: Changing Political Opportunity Structures, Policy Success and Continuing Challenges for Lesbian, Gay and Bisexual Movements. In The Lesbian and Gay Movement and the State: Comparative Insights into a Transformed Relationship. Edited by Manon Tremblay, David Paternotte and Carol Johnson. Farnham: Ashgate, pp. 181-95.

Lentin, Alana. 2008. Europe and the Silence about Race. European Journal of Social Theory 11: 487-503. [CrossRef]

Lessard-Phillips, Laurence, and Nando Sigona. 2018. Mapping EU Citizens in the UK: A Changing Profile? From 1980s to the EU Referendum. No. 3. Eurochildren Research Brief Series; Birmingham: University of Birmingham.

Marzocchi, Ottavio. 2020. Free Movement of Persons. Fact Sheets on the European Union. Brussels: European Parliament. Available online: https://www.europarl.europa.eu/ftu/pdf/en/FTU_4.1.3.pdf (accessed on 19 May 2020).

Miller, Robert. 2012. The Development of European Identity/Identities: Unfinished Business. A Policy Review. Brussels: European Commission, p. 127. Available online: https:/ec.europa.eu/research/social-sciences/pdf/policy_ reviews/development-of-european-identity-identities_en.pdf (accessed on 25 March 2020).

Moran, Leslie J., and Beverley Skeggs. 2004. Sexuality and the Politics of Violence and Safety. London: Routledge.

Moreh, Chris, Derek McGhee, and Athina Vlachantoni. 2020. The Return of Citizenship? An Empirical Assessment of Legal Integration in Times of Radical Sociolegal Transformation. International Migration Review 54: 147-76. [CrossRef]

Navaro-Yashin, Yael. 2007. Make-believe papers, legal forms and the counterfeit: Affective interactions between documents and people in Britain and Cyprus. Anthropological Theory 7: 79-98. [CrossRef]

Noy, Chaim. 2008. Sampling Knowledge: The Hermeneutics of Snowball Sampling in Qualitative Research. International Journal of Social Research Methodology 11: 327-44. [CrossRef]

Nwabuzo, Ojeaku. 2019. Racist Crime and Institutional Racism in Europe: ENAR Shadow Report 2014-2018. ENAR Shadow Report. Brussels: European Network against Racism.

Omi, Michael, and Howard Winant. 1994. Racial Formation in the United States: From the 1960s to the 1990s, 2nd ed. New York: Routledge.

Onwuachi-Willig, Angela. 2013. According to Our Hearts: Rhinelander v. Rhinelander and the Law of the Multiracial Family. New Haven: Yale University Press.

Osuji, Chinyere. 2014. Divergence or Convergence in the U.S. and Brazil: Understanding Race Relations through White Family Reactions to Black-White Interracial Couples. Qualitative Sociology 37: 93-115. [CrossRef]

Paterson, Jenny, Mark A. Walters, Rupert Brown, and Harriet Fearn. 2018. The Sussex Hate Crime Project: Final Report. Project Report. Sussex: University of Sussex. Available online: http://sro.sussex.ac.uk/id/eprint/73458/ (accessed on 7 October 2019).

Paul, Kathleen. 1997. Whitewashing Britain: Race and Citizenship in the Postwar Era, 1st ed. Ithaca: Cornell University Press. 
Razack, Sherene. 2002. When Place Becomes Race. In Race, Space, and the Law: Unmapping a White Settler Society. Edited by Sherene Razack. Toronto: Between The Lines, pp. 1-20.

Roberts, Dorothy E. 2018. Crossing Two Color Lines: Interracial Marriage and Residential Segregation in Chicago. Capital University Law Review 45: 1-32.

Rzepnikowska, Alina. 2019. Racism and xenophobia experienced by Polish migrants in the UK before and after Brexit vote. Journal of Ethnic and Migration Studies 45: 61-77. [CrossRef]

Sigona, Nando, and Marie Godin. 2019. Naturalisation and (dis)Integration for EU Families in Brexiting Britain. No. 6. Eurochildren Research Brief Series; Birmingham: University of Birmingham.

Simon, Patrick. 2017. The failure of the importation of ethno-racial statistics in Europe: Debates and controversies. Ethnic and Racial Studies 40: 2326-32. [CrossRef]

Small, Mario Luis. 2009. 'How many cases do I need?': On science and the logic of case selection in field-based research. Ethnography 10: 5-38. [CrossRef]

Steinbugler, Amy C. 2012. Beyond Loving: Intimate Racework in Lesbian, Gay, and Straight Interracial Relationships. Oxford: Oxford University Press.

Swales, Kirby. 2016. Understanding the Leave Vote. London: NatCen Social Research.

Taylor, Bridget, and Hilde de Vocht. 2011. Interviewing Separately or as Couples? Considerations of Authenticity of Method. Qualitative Health Research 21: 1576-87. [CrossRef]

Törngren, Sayaka Osanami, Nahikari Irastorza, and Dan Rodríguez-García. 2019. Understanding multiethnic and multiracial experiences globally: Towards a conceptual framework of mixedness. Journal of Ethnic and Migration Studies, 1-19. [CrossRef]

Tuckett, Anna. 2019. Managing paper trails after Windrush: Migration, documents and bureaucracy. Journal of Legal Anthropology 3: 120-23. [CrossRef]

Turner, Joe. 2015. The Family Migration Visa in the History of Marriage Restrictions: Postcolonial Relations and the UK Border. The British Journal of Politics and International Relations 17: 623-43. [CrossRef]

Twine, France Winddance. 2010. A White Side of Black Britain: Interracial Intimacy and Racial Literacy. Durham: Duke University Press.

UK Government. 1967. Sexual Offences Act 1967. Available online: http://www.legislation.gov.uk/ukpga/1967/60/ pdfs/ukpga_19670060_en.pdf (accessed on 9 June 2020).

UK Government. 1971. Immigration Act 1971. Available online: http://www.legislation.gov.uk/ukpga/1971/77/ section/3 (accessed on 31 May 2020).

UK Government. 1988. Local Government Act 1988. Available online: http://www.legislation.gov.uk/ukpga/1988/ 9/section/28/enacted (accessed on 10 June 2020).

UK Government. 1998. Human Rights Act 1998. Available online: https://www.legislation.gov.uk/ukpga/1998/42/ contents (accessed on 12 June 2020).

Valluvan, Sivamohan, and Virinder S. Kalra. 2019. Racial nationalisms: Brexit, borders and Little Englander contradictions. Ethnic and Racial Studies 42: 2393-412. [CrossRef]

Virdee, Satnam, and Brendan McGeever. 2018. Racism, Crisis, Brexit. Ethnic and Racial Studies 41: $1802-19$. [CrossRef]

Wray, Helena. 2006. An Ideal Husband? Marriage of Convenience, Moral Gate-keeping and Immigration to the UK. European Journal of Migration and Law 8: 303-20. [CrossRef]

Yeo, Colin. 2018a. The Impact of the UK-EU Agreement on Citizenship Rights for EU Families. No. 2. Eurochildren Research Brief Series; Birmingham: University of Birmingham.

Yeo, Colin. 2018b. Briefing: What Is the Hostile Environment, Where Does It Come From, Who Does it Affect? Free Movement. Available online: https:/www.freemovement.org.uk/briefing-what-is-the-hostile-environmentwhere-does-it-come-from-who-does-it-affect/ (accessed on 26 April 2020).

Yin, Robert K. 2014. Case Study Research: Design and Methods, 15th ed. Los Angeles: SAGE.

Yuval-Davis, Nira. 1997. Gender and Nation. London: SAGE Publications.

(C) 2020 by the author. Licensee MDPI, Basel, Switzerland. This article is an open access article distributed under the terms and conditions of the Creative Commons Attribution (CC BY) license (http://creativecommons.org/licenses/by/4.0/). 